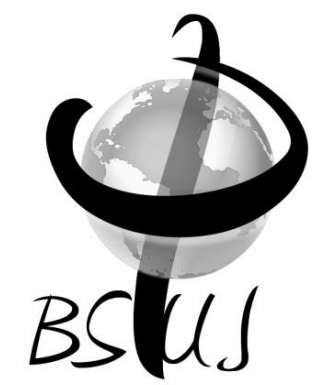

\title{
Editorial and Review Board
}

\section{BSUJ Editorial Board}

Famira Racy, Editor \& Copy Editor, Departments of Psychology and Humanities, MRU Jane Fix, Associate Editor \& Copy Editor, Department of Psychology, MRU

Tristan Smyth, External Editor, Department of English, MRU

\section{BSUJ Committee}

Alexander Christison, Department of Sociology, MRU

Famira Racy, Departments of Psychology and Humanities, MRU

Miranda MacCallum, Department of Sociology, U of C

Nicole MacInnis, Department of Sociology, U of M

Renee Ladouceur, Department of Sociology, MRU

\section{BSUJ Advisory}

Evelyn Field, Chair, Department of Psychology, MRU

Cheryl Techentin, HREB, Department of Psychology, MRU

Alain Morin, Department of Psychology, MRU

Bob Uttl, Department of Psychology, MRU

Matt Lonsdale, Copyright Advisory, MRU

Richard Hayman, Open Journal System, MRU

Nicole MacInnis, Department of Sociology, University of Manitoba

\section{BSUJ Peer-Reviewers}

Arlana Bennett, Departments of Sociology and Religious Studies, MRU

Claire Ingles, Department of Criminal Justice, MRU

Collin Cuthberg, Departments of Sociology and Political Science, MRU

Lynne Hogan, Department of Sociology

Kyle Brachman, Departments of Psychology and English, MRU

Sam Ulmer-Kroll, Department of Anthropology

\section{BSUJ Faculty-Reviewers}

David Aveline, Department of Sociology, MRU

Alain Morin, Department of Psychology,

Nancy Ogden, Department of Psychology, MRU

Douglas Murdoch, Department of Psychology, MRU

Doug King, Department of Criminal Justice, MRU

Thank you to Jeff Keshen, Dean of Arts, and the Faculty of Arts, MRU, for the ongoing support toward advancing undergraduate initiatives. 